\title{
Trademarks and the Economic Dimensions of Trademark Law in Europe and Beyond
}

\section{Morris, Patrick-Sean}

Springer

2019

Morris , P-S 2019 , Trademarks and the Economic Dimensions of Trademark Law in Europe and Beyond . in A Marciano \& G B Ramello (eds), Encyclopedia of Law and Economics . Springer , New York , pp. 2070-2076 . https://doi.org/10.1007/978-1-4614-7753-2_566

http://hdl.handle.net/10138/328918

https://doi.org/10.1007/978-1-4614-7753-2_566

unspecified

acceptedVersion

Downloaded from Helda, University of Helsinki institutional repository.

This is an electronic reprint of the original article.

This reprint may differ from the original in pagination and typographic detail.

Please cite the original version. 


\title{
Trademark Economic Activities
}

\author{
P. Sean Morris ${ }^{1}$
}

(1)Faculty of Law, University of Helsinki, 00014 Helsinki, Finland

\section{P. Sean Morris}

Email: sean.morris@helsinki.fi

\section{Synonyms: Sign; registration; firm-advertising; protection; information transactions}

\section{Definition}

Trademarks are signs that communicate the economic interest of goods manufacturers or service providers to customers with valuable information to influence their purchasing behavior. Signs which constitutes a trademark may include words, designs, colors, the shape of goods or the packaging of goods, sounds or numbers. A feature of a trademark is that they should be able to distinguish the goods and services they represent. This is one definition of a trademark as set out in transnational legislations such as the European Trade Mark Directive (EUTMD 2015/2436).

This revised version contains a new introduction focusing on the graphical representation requirement introduced by trademark reforms in Europe and a post-script assessing the graphical representation requirement.

\section{Introduction}

The economic analysis of trademark law continues to draw a number of commentaries, yet more and more, the courts are not factoring concrete economic analysis of trademark law and trademark protection in their decisions. In this entry I give an overview and status of trademarks from a law and economic perspective and suggest that trademark laws need to respond to the economic dimension that occurs on the market and consumer economic behavior. In recent years the precise contours of a trademark in jurisdictions such as Europe has changed to reflect developments in litigation and other jurisdictions. So, for example, it is now important that trademark in Europe should be able to offer representation in such a way 'which enables the competent authorities and the public to determine the clear and precise subject matter of the protection afforded to its proprietor (EUTMD, 2015: Article 3(a)).' This provision therefore removes the graphical representation requirement that previously existed in European legislation and opens up the door to non-traditional trademarks including holograms (EUTMIR, 2018, Article 3(3)(j)). Correspondingly, the European Trade Marks Regulation (EUTMR, 2017) also modifies the graphic representation requirement in order to 
harmonize trademark registration across the single market (EUTMR, 2017, Article 4(b) and create the European Union Trade Mark (EUTMR, 2017, Article 1(1)). Since 2020 member states of the EU have begun to implement the provisions of the EUTM in national laws and as such eliminates the need for a graphical representation requirements in a trademark (eg., France, Order No. 2019-1169 of 13 November 2019) or Finland (Trademarks Act, 1 May 2019). The UK, during the BREXIT transition phase, amended the Trade Marks Act 1994 to also reflect European changes to the graphic representation requirement of a trademark (Trade Marks Act 1994, as amended, §1(a)). Thus, these developments in Europe suggests that technological advancement will also be crucial to how trademarks are protected. But one of the most important observation on the elimination of the graphical representation requirement for European trademarks is that it matches the level of the United States where there is no need to demonstrate the graphical representation requirement. The removal of the graphical representation requirement for registering trademarks in Europe is significant since it allows for a more clear and precise way of presenting a trademark. Thus, a trademark that looks like an orange should exactly be that and no more. These developments also goes to the core of how economic behavior by firms and consumers generates market competition to spur growth. This is possible given that firms which historically had found it difficult to register certain marks would now be able to do so. One recent analysis of the reforms to trademark law in Europe showed that European firms have seized the opportunity to register non-traditional marks, and, when, compared to the United States over a twelve month period, European firms registered 'a higher proportion' of non-traditional marks, and as such, non-traditional marks in Europe have 'economic significance' (da Cunha and Alpman: 2020, p. 396). In what remains in the rest of this discussion, the traditional reasoning and relevance of the law and economics approach to trademarks is looked at to frame the economic significance of trademarks.

\section{Evolution of Law and Economics in Trademarks}

In cases such as Intel $v C P M$, the European Union Court of Justice (EUCJ) introduced the notion of consumer economic behavior in the context of European trademark jurisprudence. The recognition by the Court of a change in the economic behavior of consumers was arguably an overt acknowledgement of the role of economic analysis of trademarks. Trademarks as a branch of intellectual property rights have always been the gatekeeper of how businesses function in a competitive economy, and, as the face of goods, products, and services, trademarks' economic functions and regulation are essential to both the rights holder and how competitors enter the market.

Because trademarks are signs that represent the economic identity of goods and services and, in this regard, they serves as the bridge that links customers' economic behaviors to the proprietor of goods and services, then trademarks are arguably the most important aspect of intellectual property rights in a market economy because unlike other regimes such as patents and copyrights, a trademark, albeit with renewals, is essentially perpetual and generally outlives the initial rights holder(s). This perpetual nature of trademarks demonstrates that they are important in how goods, products, and services are placed on the market to guarantee fair trade among the many players that operate in a dynamic market. A dynamic market will always allow flexibility in trademark use through licensing or other methods for trademark owners to encourage fair competition.

But another dynamism of the market is the economic behavior of trademarks, and perhaps it was no surprise that the EUCJ in Intel $v$ CPM overtly calls for the economic analysis of trademarks when trademark infringement claims are made. That decision concerned changes in the economic behavior 
of the average European consumer and how such changes could cause damage to a reputable trademark. This concern by the EUCJ highlights the need for more understanding of the economic dimensions of trademark law and the real functions of trademarks in a market economy and its impact on the economic welfare of consumers.

Although the courts sporadically address the law and economic approaches to trademarks, there has long been a growing body of literature that discusses trademarks in a law and economic context. Some of the early scholars that applied law and economics approaches to trademarks include Chamberlin ( 1933) and Robinson ( 1933) when their theories of imperfect competition are factored in and, in particular, Chamberlin's reference to "product differentiation," while other scholars (Papandreou 1956; Brown 1948; Mueller 1968) also offered their perspectives on the economics of trademarks. But some of the major works on the economic analysis of trademark law emerged in the late 1980s with those by Landes and Posner ( $\underline{1987)}$ and Economides ( $\underline{1988})$ and then other contributions by scholars such as Lunney ( $\underline{1999}$ ), Ramello ( 2006), Barnes ( 2006), and Griffiths ( 2011). In recent times Morris (2017), for instance, looks at some of the ways in which trademarks contributes to market power through the product differentiation thesis.

These approaches to the economic dimension of trademark law incorporate the economic analysis of law. Arguably, the study of law and economics of trademark law began with the great transformation in the study of law and economics as a whole that had roots in the USA at the turn of the twentieth century. Legal luminaries such as Holmes ( $\underline{1897}$ ) helped to sound the trumpet for the law and economic approach when he observed that "the man of statistics and the master of economics" were ideally good tools for the law.

The Chicago School has long been seen as the driving force behind the study of law and economics in the twentieth century with renowned economists in the 1940s and 1950s that gradually built upon Marshallian (1890) price theory or other canons such as Knight (1933). But the true form of law and economics only took off in the 1960s where economists such as Stigler (1961), Director ( 1964), and Coase (1960) oversaw the ascent of the Chicago School approaches to law and economics. Stigler ( 1961$)$ played an essential role in the development of law and economics of trademarks when he developed a model of optimal consumer search behavior under which advertising reduces consumers' search costs.

There are critics of the 1960s development of law and economics under the auspices of the Chicago School, and some have even argued that the study of law and economics is rather old given that "the study of the interrelations between legal and economic progress is as old as economics itself" (Medema 2010, p. 160). But even if the origins of law and economics can be disputed, there is without a doubt that the modern phenomena that we understand today as law and economics are essentially a phenomenon that gradually developed as the Chicago School of thought in the USA blossomed in the 1960s and 1970s, even to the point where "lemons" (problems with post-sale used cars) were used to analogize information symmetry (Akerlof 1970) or, in trademark terms, the rights holder have a better idea of the quality his mark represents.

By the 1970s, other Chicagoans such as Posner had also emerged fully in his own right applying economic analyses of the law (Posner 1973), and in 1987 he produced with a colleague a seminal article that reflects similar arguments raised in Stigler's information advertising paper ( 1961$)$. The economics of advertising, as per Stigler and the search theory, essentially served as the launch pad for economic analyses of trademarks and arguably because of information that advertising portrays in particular communicating the trademark to the consumer, even if contemporary scholars believe that "advertising is patently uninformative" (Jordan and Rubin 2008, p. 19). As a result of the broader study of law and economics, the Chicago approach was transposed to a number of other 
areas such as tax law, antitrust law, criminal law, contract law, and tort law, among others (Cooter and Ulen 2012; Miceli 1997). The law and economics approach gradually moved on to the study of intellectual property rights which covered mainly patents, copyrights, and much later trademarks, and in a 1987 joint paper by Landes and Posner, the law and economics approach was applied to trademark law and to revolutionize the study of trademarks and trademark law in an economic context.

Landes and Posner ( 1987) in their seminal article which nowadays stands as the cornerstone on the economic analysis of trademark law have argued that a trademark's essential function from an economic perspective is to reduce consumer search costs. Their arguments are steeped in the Chicago School of economic tradition, in particular, what I think was a reflection of Stigler's 1961 paper on the economics of information.

An earlier paper dealing with the economics of information, albeit from a legal perspective, also discussed advertising, which broadly encompasses trademarks (Brown 1948); however, this was prior to full development of the Chicago School. Economides ( 1988) who offered a purely positive economic theory on the economic analysis of trademarks noted in particular that trademarks can serve as a barrier to entry since the trademark "can also serve to increase welfare through the reduction of an excess number of brands" (Economides, p. 536). This approach, and like many others, that offers an economic perspective falls within microeconomic theory that concerns how individuals make rational decisions (behavioral theory), and it is largely responsible for economic analysis of law and by extent trademark law. The approach in the literature that covers the economic analysis of trademark law has essentially still kept at the forefront the problems of trademarks in the competitive economic space of society in their dual role to promote competition and to reduce consumer search costs.

\section{Litigations and Consumer Economic Behavior}

In regulatory instruments such as the EUTMR (recital 3), it is explicitly noted in its recitals the desirability to promote "harmonious development of economic activities" using trademarks. In this context, there is an economic rationale for trademark law since quality and origin suggest an economic incentive for the trademark owner while giving assurances to consumers. In this regard, trademark law is the principal arbiter that protects consumers in their economic decision-making when shopping for goods that are protected under trademark law. Yet, it is those very same trademark laws that also give the trademark owner a monopoly lease to use a specific mark to designate his goods or services. The guarantees that the law provides for trademark owners include a right to prevent others from using the mark and also a right to enhance the creative and innovative process in a broad sense.

The argument that trademarks are monopolies is not entirely new and has been around for ages, for example, in the English case Blanchard v Hill (1742), trademarks were identified as "one of those monopolies." What this means, even in contemporary times, is that the exclusivity and absoluteness of trademarks make them one of those monopolies that are subjected to being abused in an anticompetitive way and affect how consumer spending decisions are made. As monopolies, the welfare effect on consumers are negative since their spending powers are dictated by the trademark that they are locked onto, which in turn creates monopoly profits for the trademark owner who has the ability to influence the purchasing habit of the consumer. Furthermore, as a branch of intellectual 
property rights, trademarks are generally seen through the lens of state-granted monopolies, and the literature that emerged over the last six decades or so generally paints trademarks as monopolies (Lunney 1999).

In a number of ways, trademarks create problems on both the market and for the consumer. For consumers the problem of trademark monopolies is that, contrary to reducing search costs, trademarks lock consumers in perpetuity - whereas consumers are loyal only to the manufacturers of the goods the trademark represents. Arguably then, consumer search costs are then limited since they do not engage in the option of the alternative and or at times (naively) assume the mark to which they are loyal represents quality. However, on occasions, consumers may find alternatives that allow them to be better off. For the market, the monopoly in trademarks erects barriers to entry for new goods on the market. This barrier to entry, in particular contemporary times, can arise from an abundance of registered trademarks that are not in use or competitors unwilling to license a mark to new entrant that will compete with them on the market. These observations highlight the gray zone in which trademarks must operate catering to the consumer and the rights holder.

However, the legal reality of trademarks' economic effects is perhaps those that are articulated by the Courts since the Courts themselves help to shape the economic activity of markets. In Qualitex Co. $v$ Jacobson, a US court was perhaps eager to formally recognize the economic dimension of trademarks and the law when it noted that consumers were essentially rational decision-makers because trademarks allow them to make better purchasing decisions and reduce their search costs ( Qualitex Co. v Jacobson, 163-164). In Europe, where the harmonization of trademark law is an integral part of the EU's internal market, the EUCJ has often echoed the economic dimension of trademarks, such as in Intel $v C P M$ where it observed the possibility of change in economic behavior due to trademark use.

Perhaps the EUCJ's more broad reading of the economic dimension of trademark protection and use was in L'Oreal v Bellure where the Court spoke of trademark's investment function. This (additional) interpretation of trademark functions suggests the wide economic value of trademarks and the role trademarks play in a fully integrated and free market. The value of a company's trademark is often the most important piece of asset that a company holds and can leverage with either for investments or loans in the company. The L'Oreal v Bellure Court was indeed right when it pointed out the investment function of trademarks because the value in a trademark is built over time due to the actual investments in a trademark such as advertising or the reputation that the mark earned. As a valuable asset within a company's portfolio trademarks plays an integral investment function (even if L'Oreal v Bellure) did not have this reasoning in mind. The implication here is that the economic function of a trademark goes beyond quality and source function but to that of economic value represented by, a form of inter-and intra-investments which are acquired over time, thereby creating a market for "goodwill."

But despite the inherent monopoly in trademarks, it is the consumer that benefits the most from trademarking activities since the investment function that trademark performs contains a positive spillover when there is increase in trademarking activities. This spillover is the promotion of more competition and the ability of consumers to rationally select goods that are based on their purchasing power. The trademark would normally signal this and influences how the consumer behaves. In dynamic markets such as the EU where national trademarks operate alongside European trademarks, consumers respond differently to external trademarks that are not well known or where such trademark does not send quality signal. Therefore, consumers can sometimes be suspicious of goods with unknown reputation that originates in a different country. Another factor that also influences consumer economic behavior toward internal and external trademarks in the EU is that of national 
consciousness and pricing. Even where a trademark signals quality in a reputable good and a new entrant uses a similar trademark to compete, the Courts have cautioned that only a change in consumer's economic behavior could harm the reputable mark. In Intel $v$ CPM, the EUCJ introduced the concept of economic behavior in the trademark lingua, suggesting the wider role of economic analyses of trademark law and behavioral patterns of consumers:

the use of the later mark is or would be detrimental to the distinctive character of the earlier mark requires evidence of a change in the economic behaviour of the average consumer of the goods or services for which the earlier mark was registered and consequent on the use of the later mark, or a serious likelihood that such a change will occur in the future. (Intel v CPM, para. 77)

From an economic point of view, the Court cautiously warns that economic changes can affect trademark use and protection. The reasoning by the EUCJ that only a change in the economic behavior of the average consumer could threaten Intel's - INTEL mark if those consumers flock to CPM's - INTELMARK trademark broadens the scope for economic analyses of trademark use and protection and how economic evidence is assessed within the confines of the law. Intel did not provide any (economic) evidence that CPM's INTELMARK was causing harm to its economic activities, and therefore the Court found no reason that Intel's mark was being threatened.

Perhaps one of the wider implications of the Intel $v$ CPM ruling by the EUCJ and its notion of change in economic behavior in the average consumer is to look to the broader economic theory of public goods and how that is related to trademark law. Given that Intel's mark is a reputable mark, there is no doubt that it creates positive externalities and therefore a magnet for competitors to free ride on. Trademarks are in a sense - public goods - and therefore an opportunity for competitors to free ride on the good will of reputable marks. In other words, information is a public good, even when embedded in a trademark. Barnes ( $\underline{2006}$ ) has similarly argued that trademark owners are information creators and such information is widely available for "all people to use" and hence, arguably is a public good. For trademark law, the implication is even grave, given that, as Barnes ( 2007) observed, both dynamic allocative efficiency and static allocative efficiency may emerge.

Because trademark protection in Europe and globally is expanding, there is an urgent need to factor in empirical evidence based on the economic behavioral patterns of consumers in trademark litigations that can be used to help the Courts arrive at conclusions that are based on economic theories. Such empirical evidence should go beyond the mere surveys that are often used in trademark litigation given that excessive trademarks are "goods in their own right" ( Plasticolor $v$ Ford, 1989, 1332). It is also useful, when discussing economic approaches of trademark law to consider other areas competition law. This is because empirical evidence suggests that trademarks are anticompetitive, for example, by serving as tying products (Smirti 1976) or due to their inherent exclusivity or market power (Morris 2012, 2017), and whether such exclusivity is being abused by trademark owners.

The market economies in which trademarks exist are expanding, and the movement of global commerce has put into sharp focus trademark use and protection and the scope of trademark law. In trademark legislations, whether international instruments such as the Trade-Related Aspects of Intellectual Property Rights (TRIPS), regional harmonization efforts at the EU, and national trademark laws, there is the need to factor in "economic effects" of those laws and how they relate to other areas of regulation in the free market.

Trademarks are no longer seen as ought to be protected but rather how to assess the economic impact of trademarks that are currently protected and are in use and what are the economic causes of trademark nonuse. The economic impact of trademarks that are in use drives consumer economic 
behavior and how the markets respond to any perceivable changes in economic behavior, and this warrants fresh approaches to the economic dimension of trademark law.

Such economic dimension should move into a new direction beyond the predominant function(s) of trademark theory such as the search cost theory or the origin source theory. This new direction may take on, for example, the reduction of barriers to entry by allowing greater flexibility in the use of trademarks by competitors, or how the economic impact of product differentiation in trademarks affects the normative process in which trademarks must operate.

Ultimately, it is the trademark laws that can respond to the normative process, and perhaps, similar to the EUCJ's recognition of change of economic behavior by the average consumer (also echoed in Environmental Manufacturing v OHIM, 2013), trademark laws, both in Europe and beyond, can begin to reform by responding to changes in the market economy which ultimately leads to greater efficiency in the competitive process for the creation of wealth. Nevertheless, the change of economic behavior test that the European Courts advocate holds interesting interpretation for the economic analyses of trademark law both in Europe and beyond, since this new direction in trademark law interpretation has raised the threshold for trademark infringement analysis.

\title{
Graphical Signs of the Times in Technological Revolutions: A Post Script
}

\begin{abstract}
The reforms of the trademarks requirement in Europe where the graphical representation requirement has been eliminated and align with the standard practice in the United States is good for firms. But at the same time, it is US firms (Dinlersoz, et al, 2018) and to some extent EU firms that are some of the major registrants of trademarks and therefore, the economic spillovers will be great for those firms. Thus, while non-traditional trademarks in Europe will now be able to find a legal base to exalt why holograms; sounds; three-dimensional shape; the use of technical requirements such as MP3 sounds amongst others can spur economic growth, there is clearly the need to ponder whether in economic terms there are too many trademarks or will new forms of trademarks give rise to "trademark congestions" (Beebe and Fromer, 2018, p. 1012). In a globalizing world, the elimination of the graphical representation requirement in Europe is a welcome one, but at the same time, other international instruments as the Madrid System administered by the World Intellectual Property Organization (WIPO) (Madrid Agreement, 1891; Madrid Protocol, 1989) leaves the requirement intact. This was further confirmed in a recent working group on the Madrid System (Working Group, 2018, para. 74). Thus, firms can register trademarks worldwide under the Madrid System giving them access to various markets. The graphical representation requirement, can, in theory, be restrictive in other markets excluding Europe and the US. At the same time, the European and US markets, can produce excessive trademarking activities through registration even if such activities are signals of innovation. Hence, a primary risk is that expanding the forms of trademarks into other areas may facilitate a deficit in informational transactions that trademarks have come to represent.
\end{abstract}

\section{Cross-References}

- Behavioural Economic Analysis 
. Economic Analysis of Law

- Efficiency

. Innovation

. Intangible Assets

. Law and Economics

- Microeconomic Theory

- Monopolization

. Trademark Dilution

\section{References}

Akerlof G (1970) The market for lemons: quality uncertainty and the market for mechanisms. Q J Econ 84:488-500

CrossRef

Barnes DW (2006) A new economics of trademarks. Northwest J Technol Intellect Prop Law 5:2267

Barnes DW (2007) Trademark externalities. Yale J Law Technol 10:1-44

Barton Beebe and Jeanne Fromer (2018). Are we running out of trademarks? An empirical study of trademark depletion and congestion. 131 Harv Law Rev 945- 1045

Brown R Jr (1948) Advertising and the public interest: legal protection of trade symbols. Yale Law J 57:1165-1206

CrossRef

Chamberlin E (1933) The theory of monopolistic competition: a re-orientation of the theory of value. Harvard University Press, Cambridge

Coase R (1960) The problem of social cost. J Law Econ 3:1-44

CrossRef

Cooter C, Ulen T (2012) Law and economics, 6th edn. Pearson, Boston 
da Cunha, IR., and Jurgita Randakeviciute-Alpman (2020), New types of marks available after the European Union trade mark reform: An analysis in the light of the U.S. trade mark law. JIPITEC 10: $375-397$.

here

Emin Dinlersoz, Nathan Goldschlag, Amanda Myers and Nikolas Zolas (2018). An anatomy of U.S. firms seeking trademark registration. NBER Working Paper 25038

Director A (1964) The parity of the economic market place. J Law Econ 7:1-10

CrossRef

Economides N (1988) The economics of trademarks. Trademark Rep 78:523-539

Griffiths A (2011) An economic perspective on trade mark law. Edward Elgar, Cheltenham CrossRef

Holmes O (1987) The path of law. Harv Law Rev 10:457-478

Jordan E, Rubin P (2008) An economic analysis of the law of false advertising. In: Mialon HM, Rubin PH (eds) Economics, law and individual rights. Routledge, London, pp 18-43

Knight F (1933) The economics of organization. University of Chicago, Chicago

Landes W, Posner R (1987) Trademark law: an economic perspective. J Law Econ 30:265-309 CrossRef

Lunney G Jr (1999) Trademark monopolies. Emory Law J 48:367-487

Marshall A (1890) Principles of economics. Macmillan, London

Medema S (2010) Chicago law and economics. In: Ross E (ed) The Elgar companion to the Chicago school of economics. Edward Elgar, Cheltenham, pp 160-174

Miceli T (1997) Economics of the law: torts, contracts, property, litigation. Oxford University Press, New York 
Morris PS (2012) The economics of distinctiveness: the road to monopolization in trademark law. Loyola Int Comp Law Rev 33:321-386

Morris PS (2017) Trademarks as sources of market power: Drugs, beers and product differentiation. Journal of Law and Commerce 35: 163 - 253.

Mueller C (1968) Sources of monopoly power: a phenomenon called 'Product Differentiation'. Am Univ Law Rev 18:1-42

Papandreou A (1956) The economic effect of trademarks. Calif Law Rev 44:503-510

CrossRef

Posner R (1973) Economic analysis of law, 1st edn. University of Chicago Press, Chicago

Ramello G (2006) What is a sign? Trademark law and economic theory. J Econ Surv 20:547-565 CrossRef

Robinson J (1933) The economics of imperfect information. Macmillan, London

Smirti S (1976) Trademarks as tying products: the presumption of economic power. St Johns Law Rev 50:689-724

Stigler G (1961) The economics of information. J Pol Econ 69:213-225

CrossRef

Working Group on the Legal Development of the Madrid System for the International Registrations of Marks, MM/LD/WG/16/12, 13 June 2019, WIPO, Geneva

Cases and Legislations

Blanchard v Hill, 26 Eng Rep 692 [1742] 
Case C-252/07, Intel Corporation Inc v CPM United Kingdom Ltd [2008], ECR I - 8823

Case C-383/12 P, Environmental Manufacturing LLP v OHIM [2013], ECR I - 0000

Case C-487/07, L’Oreal SA v Bellure NV [2009] ECR I - 05185

EUTMD, Directive (EU) 2015/2436 of 16 December 2015 to approximate the laws of the Member States relating to trade marks, OJ L 336, 23 December 2015, p. 1

EUTMR, Regulation (EU) 2017/1001 of 14 June 2017 on the European Union Trade Mark, OJ L 154, 16 June 2017, p. 1.

EUTMIR, Commission Implementing Regulation (EU) 2018/626 of 5 March 2018, OJ L 104, 24 April 2019, p. 37.

Joined Cases C-236 to C-238/08, Google France v Louis Vuitton Malletier [2010], ECR I - 02417

Lanham (Trademark) Act, 15 U.S.C. s. 1051 - 1127, 60 Stat 427 [1946]

The Madrid Agreement Concerning the International Registration of Marks of 1891, 14 April 1891, 828 UNTS 389

Protocol Relating to the Madrid Agreement Concerning the International Registration of Marks, 28 Industrial Property 253 (1989)

Plasticolor Molded Products v Ford Motor Co., 713 F. Supp 1329 [1989]

Qualitex Co. v Jacobson Products Co., 514 US S. Ct. 159 [1995]

Trade Marks Act (UK) [1994] 